\title{
Histologic Analysis of Vocal Folds in Aging Rats
}

\author{
Sung-Chan Shin ${ }^{1,2}$ (D) Ji Min Kim² (D) Hyun-Keun Kwon² (D), \\ Yong-Il Cheon ${ }^{1,2}$ (D), and Byung-Joo Lee ${ }^{1,2}$ (D)
}

'Department of Otorhinolaryngology-Head and Neck Surgery, Pusan National University School of Medicine, Busan, Korea

${ }^{2}$ Biomedical Research Institute, Pusan National University Hospital, Busan, Korea

\section{노화 쥐 성대의 조직학적 분석}

신성찬 ${ }^{1,2}$, 김지민 2 , 권현근1,2, 천용일1,2, 이병주 ${ }^{1,2}$

부산대학교 의과대학 이비인후과학교실, ${ }^{1}$ 부산대학교병원 의생명연구원 ${ }^{2}$

Background and Objectives Presbyphonia is characterized by hoarse, breathy, weak vocal intensity. Extracellular matrix (ECM) in lamina propria (LP) of the vocal folds play an important role in voice production, and change of ECM according to the aging leads to the presbyphonia. The aim of this study was to investigate the histologic analysis of aging vocal fold of rat.

Materials and Method Six and twenty two months old Sprague-Dawley rats ( $n=8$, each group) were used and classified into young (six months old rats) and old (twenty two months old rats) group. Histologic analysis and immunohistochemical staining for ECM of LP were performed. Results Overall cellular density was significantly decreased in old rat group. Elastin fibers of LP were significantly decreased in old rat group. Type I collagen was significantly increased in old rat group. Type III collagen did not show significant difference. Hyaluronic acids did not show significant difference in Alcian blue staining and immunohistochemical staining.

Conclusion Decreased general cellular density and elastin fiber and increased type I collagen were observed in the LP of vocal folds of aging rats. These ECM changes might to contribute the aging voice.

Keywords Aging; Vocal folds; Extracellular matrix; Histology.

\section{서 론}

대한민국은 2000년 기준 65세 이상 노인 인구 비율이 $7.2 \%$ 에 이르러 이미 고령화 사 회에 접어들었고, 2026년에는 65세 이상 노인 인구 비율이 $20.8 \%$ 로 전망되어, 이른바 초 고령화 사회(super-aged society)에 접어들 것으로 예상된다. ${ }^{1)}$ 갈수록 늘어가는 노인 인 구들은 이전 노인들에 비해 건강에 관심이 많으며, 노년의 삶의 질 또한 사회적으로 중요 한 문제이다.

노인성 음성은 기식성, 진전, 음성 강도의 약화, 최대 발성 시간의 감소 등을 특징으로 하며, ${ }^{2}$ 노인성 음성을 유발하는 요인으로는 성대 근육의 위축, 성대 고유층의 조직학적 변화, 폐활량의 저하, 호흡 근육의 약화, 구강 및 성도의 구조적인 변화들이 복합적으로
Received November 3, 2020

Revised November 19, 2020

Accepted December 3, 2020

\section{Corresponding Author}

Byung-Joo Lee, MD, PhD

Department of Otorhinolaryngology-

Head and Neck Surgery,

Pusan National University

School of Medicine,

179 Gudeok-ro, Seo-gu,

Busan 49241, Korea

Tel +82-51-240-7675

Fax+82-51-240-2162

E-mail voiceleebj@gmail.com

\section{ORCID iDs}

Sung-Chan Shin (D)

https://orcid.org/0000-0003-2329-0648 Ji Min Kim (D)

https://orcid.org/0000-0002-3608-765X Hyun-Keun Kwon (D) https://orcid.org/0000-0003-4089-8639 Yong-II Cheon (D)

https://orcid.org/0000-0003-0288-0542

Byung-Joo Lee (D)

https://orcid.org/0000-0001-7091-6688

This is an Open Access article distributed under the terms of the Creative Commons Attribution Non-Commercial License (https://creativecommons.org/ licenses/by-nc/4.0) which permits unrestricted non-commercial use, distribution, and reproduction in any medium, provided the original work is properly cited. 
작용하는 것으로 알려져 있다. ${ }^{3)}$ 이 중 성대 진동에 중요한 역 할을 하는 고유층의 조직학적 변화는 노인성 음성을 이해하 는데 있어 중요한 부분으로 생각된다.

쥐는 유전적으로 인간과 유사한 점이 많고, 20 개월 이상만 되어도 인간의 노년에 해당하므로, 노화 연구에 좋은 동물이 고, ${ }^{4)}$ 노화 성대의 조직학적 변화가 인간 노화 성대의 조직학 적 변화와 유사한 경향을 보이므로, 노화 쥐는 노인성 음성 변화 연구에 적합한 모델로 생각된다. ${ }^{5-8)}$ 본 연구의 목적은 노화 쥐에서 성대 고유층의 조직학적 변화를 분석하여, 노인 성 음성을 이해하고 연구하는 데 있어 도움이 되고자 함이다.

\section{대상 및 방법}

\section{동물 모델 및 표본 제작}

본 연구를 위한 동물조직은 부산대학교 생명윤리위원회 승 인(PNU-2017-1428) 획득 후, 부산대학교 약학대학 노화조직 은행(Aging Tissue Bank)으로부터 후두 조직을 제공받아서 사용하였다. 생후 6개월의 수컷 쥐(Sprague Dawley ${ }^{\circledR}$, Samtako Bio lnc., Osan, Korea)와 생후 22개월의 수컷 쥐를 각 각 8 마리씩 사용하였다. Sprague Dawley종의 쥐는 평균 수명 이 30개월 정도로 보고되며, 6개월 쥐는 사람으로 치면 성년 에 해당하고, 22 개월 쥐는 인체 나이 60 세 정도에 해당되어, 6 개월 쥐와 22 개월 쥐를 젊은 쥐와 노화 쥐 그룹으로 설정하 였다.) 성대를 포함하는 후두 조직은 $4 \%$ formaldehyde 용액 에 보관 후 탈수하였고 파라핀 임베딩(Leica TP1020, Semienclosed benchtop tissue processor, Leica Wetzlar, Germany) 및 디스 펜싱(Leica EG1150H, Heated paraffin embedding module, Leica)을 위해 자동 티슈 프로세서를 사용 하여 paraffin block을 $4 \mu \mathrm{m}$ 두께로 절편을 만들어 슬라이 드로 제작하였다.

\section{조직 표본 염색}

염색 분석을 위해 슬라이드를 자일렌으로 탈파라핀화한 다음 $100 \%$ 에탄올, $85 \%$ 에탄올, $75 \%$ 에탄올, $50 \%$ 에탄올 및 마지막으로 물로 일련의 세척을 통해 수화하였다. 각 성대 조 직의 전체 양상 비교를 위해 haematoxylin and eosin(H\&E) 염색을 하였고, 엘라스틴 섬유 밀도를 비교하기 위해 Verhoeff's elastin 염색을 하였으며, 히알루론산(hyaluronic acid) 변화 를 비교하기 위해 면역조직화학 염색을 하였다.

\section{면역조직화학 염색}

탈파라핀화된 섹션을 phosphate buffered saline(PBS)로 세척하고 PBS 중 $0.3 \%$ Triton X-100을 함유하는 2\% bovine serum albumin(BSA)로 실온에서 1시간 동안 차단하였다. 일 차 항체는 anti-hyaluronic acid, anti-collagen I, anti-collagen III(1:400)(Abcam, Cambridge, U.K.)을 사용하여 각각 $4^{\circ} \mathrm{C}$ 에서 24 시간 동안 반응시켰다. 일차 항체를 세척한 후, 섹 션을 실온에서 1 시간 동안 이차 항체에 반응시켰다. Goatanti rabbit secondary antibodies(1:1,000)(ENZO Biochem, Farmingdale, NY, USA)를 3,3-diaminobenzidine(DAB) 염색을 사용한 이중 염색 목적에 사용하였고, 일차 항체 대신 $1 \% \mathrm{BSA}$ 로 보충된 $\mathrm{PBS}$ 를 사용한 배양은 음성대조군으로 사 용하였다.

\section{관찰 방법 및 통계 분석}

조직 분석을 위해 각 군별로 고유층의 중심부에서 200 배 배율하에 광학 현미경(versatile upright microscope for materials analysis, Leica DM4000/600M, Leica)으로 사진을 획득한 후 염색된 부분을 정량 분석하였다. 고유층 조직의 중 간 부분을 선택하여 대표 사진을 획득하였다. 염색 후 정량 분 석을 위해 광학 현미경으로 구성된 시스템을 사용하여 이미 지 분석을 통해 양성으로 염색된 영역의 측정을 수행하였다. 형태 측정은 광학 현미경으로 구성된 이미지 분석 시스템 프 로그램(Leica Basic LAS V3.8 software, Leica)을 사용하여 40배 배율로 획득한 고유층의 현미경 사진을 이용하였다. 성 대 고유층의 면역 조직 화학적 분석을 위해 400 배 배율에서 3 개의 비중첩 영역의 사진을 획득하여, 각 섹션에서 총 9 개의 영역을 분석했다. 결과는 총 면적당 염색 면적 $\left(\mu \mathrm{m}^{2}\right)$ 으로 표현 되었다. 데이터는 중앙값과 범위로 표현되었다. 통계 측정은 GraphPad (GraphPad Software version 5.0 Inc., San Diego, CA, USA) 프로그램을 사용하여 Mann-Whitney U test로 통 계 분석하였으며, $\mathrm{p}$-value가 0.05 미만인 경우를 통계학적으 로 유의한 것으로 간주하였다.

\section{결 과}

$\mathrm{H \& E}$ 염색에서 전체적인 세포의 밀도는 노화 쥐군에서 유 의하게 감소하였다 $\left(100.00 \pm 16.02 \mu \mathrm{m}^{2} / \mathrm{pixel}^{2}\right.$ vs. $86.19 \pm 8.33$ $\mu \mathrm{m}^{2} / \mathrm{pixel}^{2}, \mathrm{p}<0.05$ )(Fig. 1). 엘라스틴 역시 노화 쥐군에서 유 의하게 감소하였다(100.00 $\pm 34.7 \mu \mathrm{m}^{2} / \mathrm{pixel}^{2}$ vs. $62.81 \pm 31.80$ $\mu^{2} / \mathrm{pixel}^{2}, \mathrm{p}<0.05$ )(Fig. 2). 면역조직화학 염색에서 1형 콜라 겐은 노화 쥐군에서 유의하게 증가하였다(100.00 $\pm 25.61 \mu \mathrm{m}^{2} /$ pixel $^{2}$ vs. 136.34 $\pm 40.50 \mu \mathrm{m}^{2} / \mathrm{pixel}^{2}, \mathrm{p}<0.05$ ) (Fig. 3). 3형 콜 라겐은 젊은 쥐군과 노화 쥐군에서 유의한 차이가 없었으며 $\left(100.00 \pm 23.82 \mu \mathrm{m}^{2} /\right.$ pixel $^{2}$ vs. $94.15 \pm 17.92 \mu \mathrm{m}^{2} /$ pixel $\left.^{2}\right)$ (Fig. 4), Alcian blue 염색과 면역조직화학 염색에서 히알루론산 역 

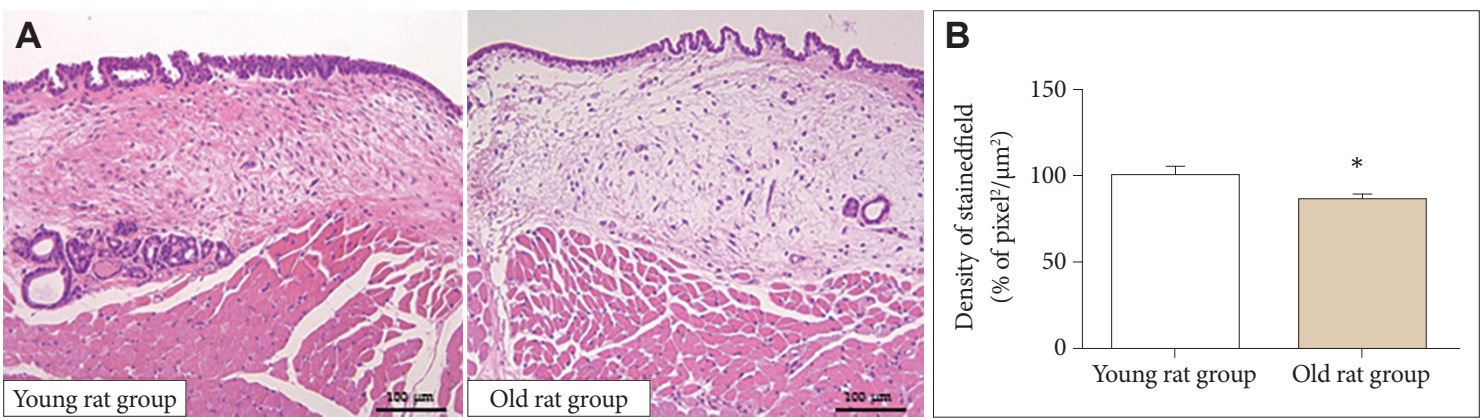

Fig. 1. General morphologic analysis. A: General cellular density was decreased in old rat group compared to young rat group in haematoxylin and eosin staining $(\times 40)$. B: Old rat group showed decreased general cellular density in quantitative analysis. ${ }^{*} p<0.05$.
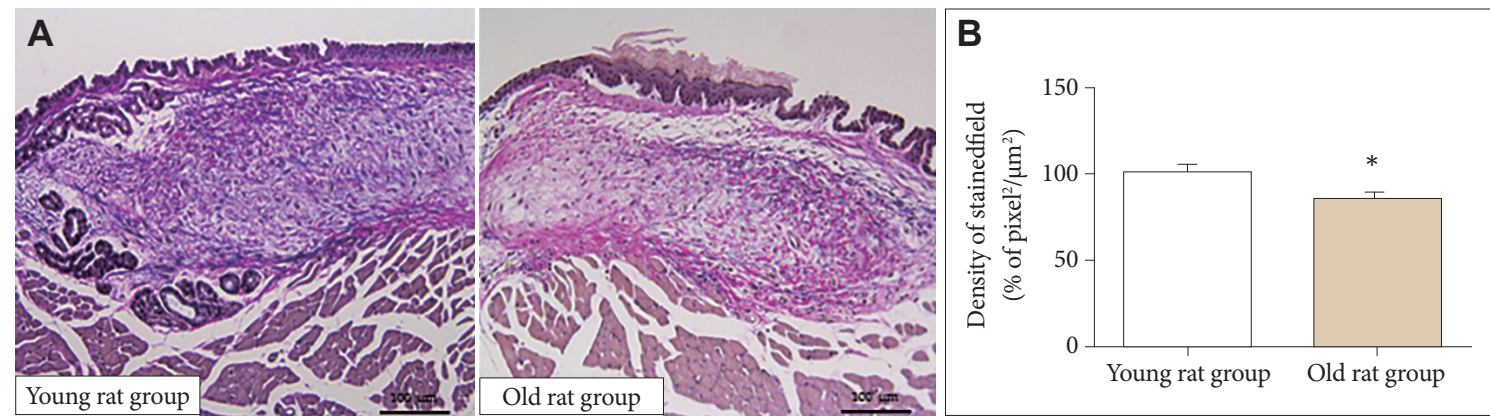

Fig. 2. Elastin of LP. A: Elastin was decreased in old rat group compared to young rat group in Verhoeff's staining $(\times 40)$. B: Old rat group showed decreased elastin in LP in quantitative analysis. LP: lamina propria. ${ }^{*} p<0.05$.
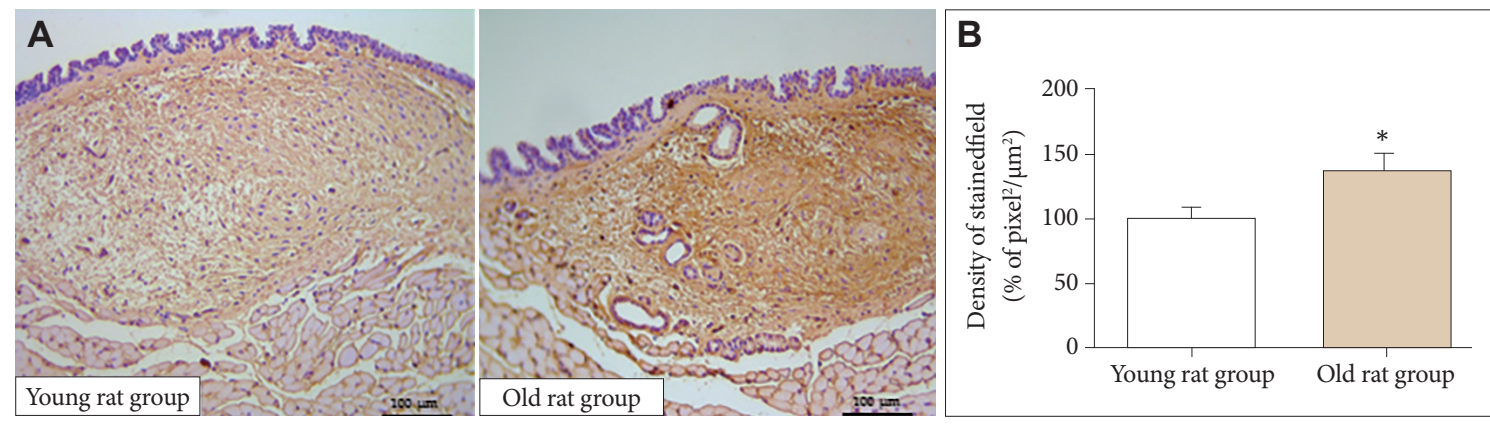

Fig. 3. Type I collagen of LP. A: The expression of type I collagen of old rat group was significantly lower than young rat group in immunohistochemical staining $(\times 40)$. B: Old rat group showed significantly decreased type I collagen in LP in quantitative analysis. LP: lamina propria. ${ }^{*} \mathrm{p}<0.05$.

시 젊은 쥐와 노화 쥐에서 유의한 차이가 없었다 $(3.51 \pm 2.50$ $\mu \mathrm{m}^{2} /$ pixel $^{2}$ vs. $3.43 \pm 3.90 \mu \mathrm{m}^{2} /$ pixel $^{2}$ )(Fig. 5).

\section{고 찰}

노화에 따른 후두의 변화는 대사성, 영양학적, 유전학적, 내분비적 요소가 복합적으로 작용하여 발생하며, 구조적으로 는 후두의 연골부터 후두 근육, 성대의 고유층까지 다양한 부 분에 걸쳐 발생한다. 후두의 근육은 일반적으로 나이가 듦에 따라 점차 위축되는 것으로 알려져 있고, 이에 따라 성대는 얇아지고, 휘어지게(bowing) 되어, 성문폐쇄부전(glottal in- competency)을 발생시킨다." 또한 근육의 약화에 의해 성문 하압(subglottic pressure)이 감소하여, 목소리의 크기(vocal loudness)가 감소하며, 여성에서는 음도가 낮아지고, 남성에서 는 높아지는 경향을 보인다. ${ }^{3,10)}$

성대의 진동을 결정하는 데 있어 중요한 역할을 하는 것은 성대의 고유층이며, 성대 고유층을 구성하고 있는 세포외 기질 (extracellular matrix)은 노화에 따라 양적, 질적 변화를 수반 한다. 성대의 고유층은 상층(superficial layer), 중층(intermediate layer), 심층(deep layer)으로 구분되며, 콜라겐, 엘라스 틴, 히알루론산 등으로 구성된 다양한 세포외 기질로 구성되 어 있다. 고유층의 상층은 상대적으로 콜라겐, 엘라스틴의 분 

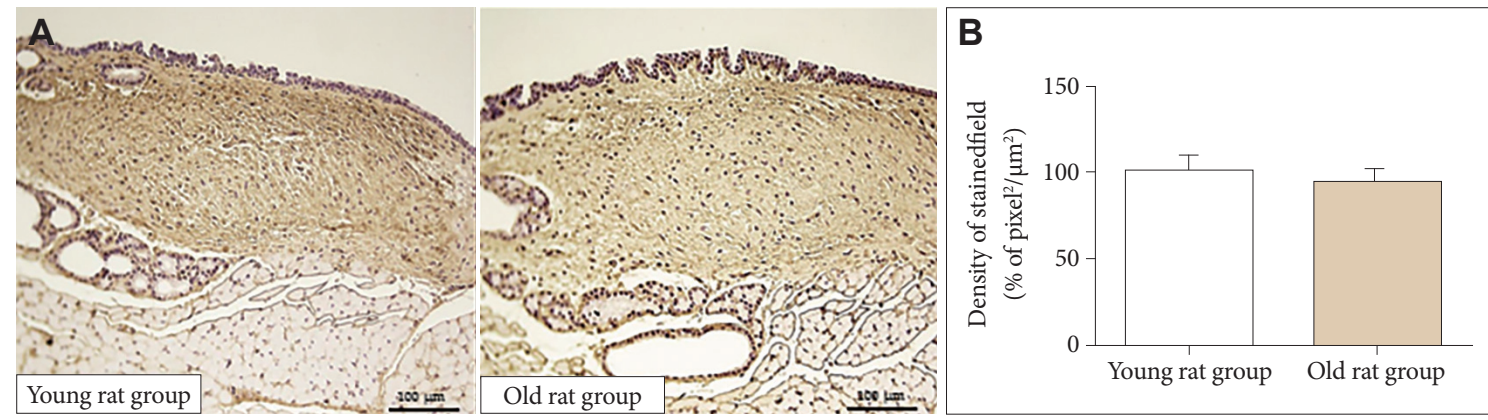

Fig. 4. Type III collagen of lamina propria. A: The expression of type I collagen was not significantly different between the old and young rat group in immunohistochemical staining $(\times 40)$. B: In quantitative analysis, both two group did not show significant differences.
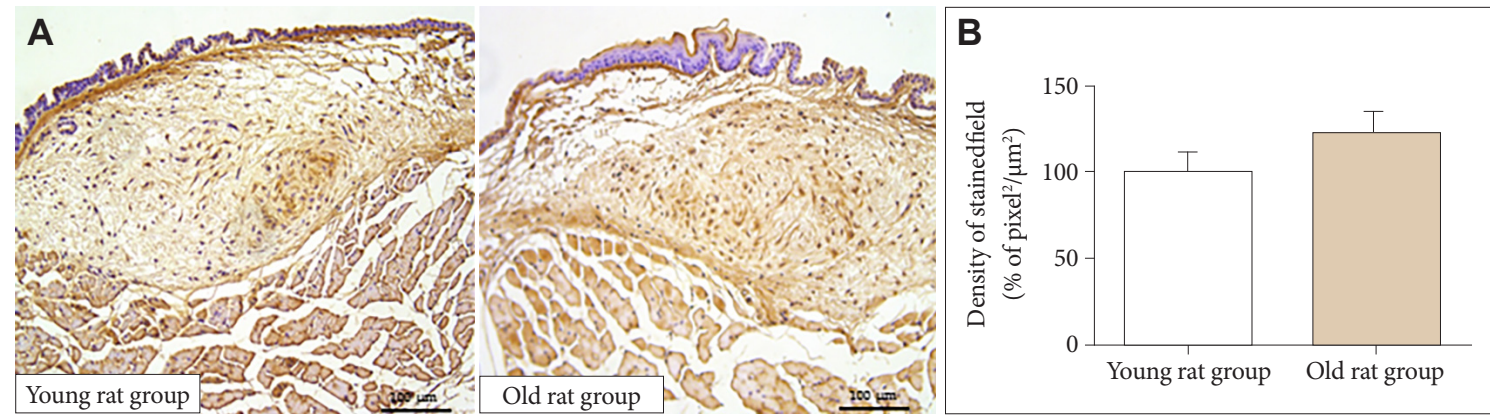

Fig. 5. Hyaluronic acids of lamina propria. A: The expression of hyaluronic acid was not significantly different between the old and young rat group in immunohistochemical staining $(\times 40)$. B: In quantitative analysis, both two group did not show significant differences.

포가 적어 다소 유연하여, 콜라겐, 엘라스틴의 분포가 높아 상 대적으로 단단한 중층과 심층 위에서 유연하게 움직여 성대의 진동을 생성한다고 알려져 있다(body-cover theory). ${ }^{3)}$ 따라 서 성대의 진동에 중요한 고유층의 세포외 기질의 노화에 따 른 변화는 노인성 음성을 이해함에 있어 중요한 부분이다.

과거 여러 연구들에 의하면 노화에 따른 성대 고유층의 세 포외기질은 1형 콜라겐은 증가, 3형 콜라겐은 감소하고, 엘라 스틴과 히알루론산은 감소하는 것으로 알려져 있다. ${ }^{5,6)}$ 성대 고유층의 세 층을 구분하여 살펴보면, 1 형 콜라겐은 고유층 전체에서 전반적인 증가를 보이며, 엘라스틴은 심층에서는 밀 도가 증가하나, 상층에서는 분포가 적어지는 경향을 보였다. 히알루론산은 고유층 전체에서 감소하는 경향을 보였다. ${ }^{7)}$ 이러한 세포외 기질 조성 변화는 성대 반흔에서 관찰되는 변 화와 유사하며, ${ }^{12)}$ 고유층의 점도(viscoelasticity)가 감소하고, 강직도(stiffness)가 증가하여 양질의 성대 진동을 저해하는 것 으로 생각된다. 그러나 본 연구에서는 노화 성대에서 1형 콜라 겐 증가와 엘라스틴 감소는 관찰되었지만, 3형 콜라겐과 히알 루론산은 유의한 차이를 보이지 않았고, 이는 기존의 연구 결 과(고유층의 콜라겐 증가, 히알루론산 감소)와 다소 상반된 다.1) 이러한 이유로는 상대적으로 적은 표본 수가 영향을 주 었던 것으로 생각된다.

최근 $\mathrm{Kim}$ 등 $^{12)}$ 은 노화에 따른 성대의 변화는 폐경 같은 성 호르몬에 의한 변화가 중요할 역할을 할 것으로 생각되어, 실
험 쥐에서 고환과 난소를 제거하여 성대 고유층의 변화를 관 찰하였다. 실험 쥐에서 고환을 제거한 후 3 개월에 남성 호르몬 의 수치는 감소하였지만, 성대 고유층의 세포외 기질의 변화는 없었다. 그러나 난소를 제거한 실험 쥐의 세포외 기질에서는 히 알루론산의 감소, 엘라스틴의 감소, 1 형 콜라겐의 증가가 관찰 되었다. ${ }^{12)}$ 그리고 이러한 폐경에 의한 성대고유층의 조직 변화 는 echinochrome $\mathrm{A}$ 라는 성게에서 추출한 해양 유래 물질의 항산화 작용에 의해 예방되는 것을 보고하였다. ${ }^{13)}$ 이처럼 노 화 성대의 세포외 기질 변화는 폐경 같은 호르몬 변화 및 노 화에 따른 조직의 활성산소 생성도 중요한 영향을 미치는 것 으로 생각된다.

또한 노화 성대의 세포외 기질의 변화들이 초래되는 원인이 성대 고유층내 섬유아세포(fibroblast)의 기능 변화로 설명되 기도 한다. Chen과 Thibeault ${ }^{5)}$ 는 노인성대에서 분리 배양한 섬유아세포의 세포외 기질 생성 능력이 젊은 연령에 비해 감 소한 것을 확인하였다. 또한 노화 성대 내부의 콜라겐의 배열 은 젊은 연령에 비해 불규칙적이고 혼란스러운 상태(disorganization)로 변화되며, 콜라겐의 분해능이 저하(decreased remodeling)되어 점차적으로 콜라겐이 축적되어, 고유층의 강직도는 증가하고, 유연성은 감소하게 된다. ${ }^{14,15)}$ 최근에는 노 화 쥐의 성대 고유층의 섬유아세포에서 칼슘 채널이 증가하 는 것이 보고되어, 성대 고유층의 노화 기전으로 칼슘 채널 변 화의 가능성을 제시되었다. ${ }^{16)}$ 
노인성 음성은 성대 근육 약화에 따른 성문폐쇄부전과 더 불어 성대 고유층의 세포외 기질의 변화에 의한 성대 진동 양 상의 변화에 의해 발생하는 것으로 생각된다. 이러한 노화 성 대의 세포외 기질 변화는 노화 과정 자체로 설명하는 것 이외 에도 폐경 같은 호르몬 변화나 노화 과정에 따른 활성산소 생 성으로 인한 조직 손상도 주요 요인으로 생각된다. 향후 성대 노화에 의한 성대 고유층의 세포외 기질 변화를 예방하는 여 러 가지 약물(성장인자, 항산화 물질)이나 줄기세포를 이용한 치료법이 기대된다. ${ }^{13,17-20)}$

본 연구의 한계점으로는 노화 성대 연구를 위해 동물 성대 조직 분석은 기존의 여러 보고들이 존재한다는 점과, 조직학 적 변화를 초래한 기전에 대한 연구가 포함되지 못했다는 점 이다. 그러나 $\operatorname{Lim}$ 등 $^{11)}$ 이 보고한 이전 연구에서 조금 더 나아 가 본 연구에서는 세포외 기질을 1형, 3형 콜라겐, 엘라스틴, 히알루론산으로 나눠 H\&E 염색, Verhoeff's elastin 염색 및 immunohistochemical 염색을 시행하여 세분화해서 조직 분 석을 하였다는데 본 연구의 의의가 있다. 또한 조직학적 변화 를 초래하는 mRNA, 단백 및 섬유아세포 수준에 대한 연구 와 노화 성대의 진동과 점탄성이 감소되었는지에 대한 기능 적 분석은 진행되지 못했다는 점도 한계점으로 생각된다. 그 러나 쥐는 유전적으로 인간과 유사한 점이 많고, 20개월 이상 만 되어도 인간의 노년에 해당하므로, 노화 연구에 좋은 동물 이고, 노화 성대의 조직학적 변화가 인간 노화 성대의 조직학 적 변화와 유사한 경향을 보이므로, 노화 쥐는 노인성 음성 변화 연구에 적합한 모델로 생각되며, 본 연구 결과를 토대로 향후 기능적 변화 및 세포, 단백질 수준의 분석이 이뤄져야할 것으로 생각된다.

\section{결 론}

노화 쥐 성대에서 1형 콜라겐은 증가되었고, 엘라스틴은 감 소하였다. 3형 콜라겐과 히알루론산은 유의한 차이를 보이지 않았다. 이러한 성대 고유층의 세포외 기질 조성 변화는 노인 성 음성 변화를 이해하는데 있어 중요한 부분으로 생각된다.

중심 단어: 노화, 성대, 세포외 기질, 조직.

\section{Acknowledgments}

None.

Conflicts of Interest

The authors have no financial conflicts of interest.

Authors' Contribution

Conceptualization: Byung-Joo Lee. Data curation: Sung-Chan Shin,
Ji Min Kim. Validation: Hyun-Keun Kwon, Yong-Il Cheon. Visualization: Ji Min Kim. Writing_original draft: Sung-Chan Shin. Writing_review \& editing: Byung-Joo Lee. Approval of final manuscript: all authors.

\section{REFERENCES}

1. United Nations, Department of Economic and Social Affairs, Population Division. World population ageing 2019: highlights. New York, NY: United Nations;2019.

2. Baek MK, Kim DY. Clinical manifestation of aging voice. J Korean Society Laryngol Logopedics Phoniastrics 2014;25(1):16-9.

3. Hirano M. Morphological structure of the vocal cord as a vibrator and its variations. Folia Phoniatr (Basel) 1974;26(2):89-94.

4. Sengupta P. The laboratory rat: relating its age with human's. Int J Prev Med 2013;4(6):624-30.

5. Chen X, Thibeault SL. Characteristics of age-related changes in cultured human vocal fold fibroblasts. Laryngoscope 2008;118(9):1700-4.

6. Branco A, Todorovic Fabro A, Gonçalves TM, Garcia Martins RH. Alterations in extracellular matrix composition in the aging larynx. Otolaryngol Head Neck Surg 2015;152(2):302-7.

7. Ohno T, Hirano S, Rousseau B. Age-associated changes in the expression and deposition of vocal fold collagen and hyaluronan. Ann Otol Rhinol Laryngol 2009;118(10):735-41.

8. Hirano S, Minamiguchi S, Yamashita M, Ohno T, Kanemaru S, Kitamura M. Histologic characterization of human scarred vocal folds. J Voice 2009;23(4):399-407.

9. Martins RH, Benito Pessin AB, Nassib DJ, Branco A, Rodrigues SA, Matheus SM. Aging voice and the laryngeal muscle atrophy. Laryngoscope 2015;125(11):2518-21.

10. Mifune E, Justino VSS, Camargo Z, Gregio F. Acoustic analysis of aging voice: fundamental frequency characterization. Revista CEFAC 2007;9(2):238-47.

11. Lim DW, Choi JS, Lim JY, Kim YM. Histologic changes of vocal fold aging in a rat model. Korean J Otorhinolaryngol-Head Neck Surg 2013; 56(8):506-10.

12. Kim JM, Shin SC, Park GC, Lee JC, Jeon YK, Ahn SJ, et al. Effect of sex hormones on extracellular matrix of lamina propria in rat vocal fold. Laryngoscope 2020;130(3):732-40.

13. Kim JM, Kim JH, Shin SC, Park GC, Kim HS, Kim K, et al. The protective effect of echinochrome a on extracellular matrix of vocal folds in ovariectomized rats. Mar Drugs 2020;18(2):77.

14. Hirano M, Sato K, Nakashima T. Fibroblasts in geriatric vocal fold mucosa. Acta Otolaryngol 2000;120(2):336-40.

15. Sato K, Hirano M, Nakashima T. Age-related changes of collagenous fibers in the human vocal fold mucosa. Ann Otol Rhinol Laryngol 2002;111(1):15-20.

16. Kim JM, Heo HS, Shin SC, Kwon HK, Lee JC, Sung ES, et al. Increased calcium channel in the lamina propria of aging rat. Aging (Albany NY) 2019;11(20):8810-24.

17. Ohno T, Hirano S. Treatment of aging vocal folds: novel approaches. Curr Opin Otolaryngol Head Neck Surg 2014;22(6):472-6.

18. Seo Y, Shin TH, Ahn JS, Oh SJ, Shin YY, Yang JW, et al. Human tonsil-derived mesenchymal stromal cells maintain proliferating and ros-regulatory properties via stanniocalcin-1. Cells 2020;9(3):636.

19. Shin SC, Seo Y, Park HY, Jung DW, Shin TH, Son H, et al. Regenerative potential of tonsil mesenchymal stem cells on surgical cutaneous defect. Cell Death Dis 2018;9(2):183.

20. Lee BJ. Tissue engineering for treatment of vocal fold scar. J Clinical Otolaryngol 2010;21(2):191-8. 